\title{
Effects of Soil Decompaction and Amendment on Root Growth and Architecture in Red Maple (Acer rubrum)
}

\author{
William Hascher and Christina E. Wells
}

\begin{abstract}
The Terravent ${ }^{\mathrm{TM}}$ soil injection device (Pinnacle Concepts, Ltd., Cornwall, UK) uses compressed nitrogen gas to fracture compacted soil and permits the subsequent injection of liquid amendments. In the current study, we measured fine root growth and architecture in soil that had received one of four treatments: 1) Terravent injections, 2) Terravent injections followed by liquid amendment (MycorTree ${ }^{\circledR}$ Injectable; PHC, Inc., Pittsburgh, PA, U.S.), 3) addition of amendment only, and 4) an untreated control. The experiment was conducted on ten red maples (Acer rubrum) growing on a moderately compacted urban clay soil next to a busy road on the Clemson University campus. Treatments were applied in April 2002. Seven weeks later, soil cores were pulled from locations adjacent to the injection sites, and fine roots (less than $2 \mathrm{~mm}$ [0.08 in] in diameter) from each core were washed free of soil. A variety of root parameters were measured, including length, surface area, diameter distribution, and mass. Terravent treatment had no effect on any root parameters measured. Application of MycorTree was associated with small, statistically significant reductions in root diameter, root mass density (mg $\mathrm{root} / \mathrm{cm}^{3}$ soil), and root surface area density $\left(\mathrm{cm}^{2} \mathrm{root} / \mathrm{cm}^{3}\right.$ soil).
\end{abstract}

Key Words. Acer rubrum; root growth; soil decompaction.

Urban soils experience significant compaction as a result of mechanical disturbance and grading during construction. Later, these soils may be further compacted by pedestrian, equipment, and vehicular traffic. Consequently, urban soils frequently exhibit significant resistance to root penetration, reduced water infiltration, and low rates of oxygen diffusion, all of which can impair the growth and function of tree roots (Patterson and Mader 1982; Day and Bassuk 1994).

Pneumatic injection devices for the mitigation of soil compaction around urban trees were first introduced in the early decades of the 20th century. These devices injected pressurized air into the soil to fracture compacted layers and improve root growth conditions. Some were fitted with a hopper from which dry fill material could be released into the fracture planes to hold them open (Smiley et al. 1990).

Research has not demonstrated a consistent benefit to soil treatment with pneumatic injection devices. Air injections have sometimes improved soil physical properties, but these results have been highly dependent on location and soil type (Smiley et al. 1990; Rolf 1994; Smiley 1994, 2001). Air injection treatments had no effect on trunk diameter growth in four tree species (Smiley 1994), and similar results were reported for shoot growth, plant height, and aboveground dry mass in five tree species (Rolf 1994).

To date, no research has addressed fine root growth response to soil injection treatments. Injection treatments have the potential to reduce mechanical impedance and increase root elongation in compacted soils. Furthermore, the opening of cracks and fissures may increase water and oxygen availability in the root zone, stimulating root growth and activity.

In this experiment, we evaluated a relatively new soil injection device, the Terravent ${ }^{\mathrm{TM}}$ (Pinnacle Concepts, Ltd., Cornwall, UK), for its ability to increase fine root length density of red maple (Acer rubrum) growing in moderately compacted urban soil. The Terravent injects high-pressure nitrogen gas through a perforated steel pipe that is driven into the soil. Previous work has shown that the resulting fractures occur approximately $23 \mathrm{~cm}$ (9.2 in) below the soil surface and are horizontal to convex with widths up to $56 \mathrm{~cm}$ (22.4 in) (Smiley 2001).

After the initial high-pressure nitrogen injections, liquid amendments may be released into the fractures. In this experiment, a commercial liquid soil amendment containing mycorrhizal inoculum and numerous other ingredients (MycorTree $^{\circledR}$ Injectable; PHC, Inc., Pittsburgh, PA, U.S.) was tested with and without initial Terravent injections.

\section{MATERIALS AND METHODS}

\section{Site Characterization}

The study was conducted on ten red maple (Acer rubrum) trees growing along a busy road at the Clemson University campus in Clemson, South Carolina, U.S. The trees ranged in diameter from 28 to $66 \mathrm{~cm}$ (11.2 to 26.4 in) and had canopy diameters ranging from 6 to $9 \mathrm{~m}$ (19.8 to $29.7 \mathrm{ft})$. The larger 
trees were approximately 25 to 30 years old. All trees were surrounded by turf and had been mulched annually to a diameter of $3.7 \mathrm{~m}(12.21 \mathrm{ft})$.

Soil at the site was a Cecil clay that had undergone significant disturbance and compaction from past agricultural activity, grading, grounds maintenance equipment, and seasonal vehicle parking. Soil bulk densities at the site ranged from $1.38 \mathrm{~g} / \mathrm{cm}^{3}$ to $1.86 \mathrm{~g} / \mathrm{cm}^{3}$ with an average bulk density of $1.62 \mathrm{~g} / \mathrm{cm}^{3}$. For soils of this texture, bulk densities above 1.5 are restrictive to root growth (USDA-NRCS 1999).

Two months before treatment application, glyphosate herbicide (Roundup ${ }^{\mathrm{TM}}$; Monsanto, St. Louis, MO) was sprayed within the diameter of each mulch ring at the recommended label rate, and shredded bark mulch was applied to create a uniform mulch depth of $10 \mathrm{~cm}$ (4 in). Herbicide was occasionally spot-sprayed thereafter to eliminate weed root contamination beneath the experimental trees.

\section{Experimental Design}

The experiment used a randomized complete block experimental design with a $2 \times 2$ factorial treatment structure $( \pm$ Terravent, \pm liquid amendment) in which individual trees served as blocks. Under each tree, a circular sampling area of $24 \mathrm{~m}^{2}\left(259.2 \mathrm{ft}^{2}\right)$ was identified and divided into four quadrants centered around the trunk. Five injection sites were marked within each quadrant for a total of 20 injection sites per tree.

Treatments included: 1) Terravent injection only (TV); 2) Terravent injection followed by release of MycorTree liquid soil amendment $(\mathrm{TV}+\mathrm{M})$; 3) addition of liquid amendment only (M); and 4) an untreated control (C). Each of the four treatment combinations was randomly assigned to one quadrant beneath each tree for a total of ten replicates per treatment.

\section{Treatment Application}

Treatments were applied on 2 April 2002. The TV treatment consisted of five 82.7 bar (1200 psi) $\mathrm{N}_{2}$ injections per quadrant spaced $88 \mathrm{~cm}$ (35.2 in) apart. The Terravent was equipped with a $20 \mathrm{~cm}$ (8 in) probe and a clay model power head.

$\mathrm{TV}+\mathrm{M}$ treatment consisted of 83 bar (1200 psi) $\mathrm{N}_{2}$ gas injections followed by the release of $118 \mathrm{~mL}(3.54 \mathrm{fl} \mathrm{oz})$ of MycorTree Injectable product at a pressure of 10 bars (150 psi). The product had been mixed water at the manufacturer's recommended rate.

The $\mathrm{M}$ treatment consisted of liquid amendment addition only. Again, $118 \mathrm{~mL}(3.54 \mathrm{fl} \mathrm{oz})$ of the suspension was released into each injection site at a pressure of 10 bars (150 psi). No injections of any kind were made in the untreated $\mathrm{C}$ quadrants.

MycorTree Injectable contains endo- and ectomycorrhizal spores, rhizosphere bacteria, and a variety of abiotic ingredi- ents, including humic acids, seaweed extracts, and intermediate metabolites. Based on the manufacturer's ingredient list, each $118 \mathrm{~mL}$ (3.54 fl oz) injection contained approximately 64 endomycorrhizal spores, $17.4 \times 10^{6}$ colony-forming units of bacteria, $0.055 \mathrm{~g}\left(1.94 \times 10^{-3} \mathrm{oz}\right)$ of humic acid, and 0.058 $\mathrm{g}\left(2.06 \times 10^{-3} \mathrm{oz}\right)$ of seaweed extract, among other ingredients. Ectomycorrhizal spores were also present in each injection, but the presence of these propagules was not relevant for red maple, which only forms endomycorrhizal associations.

\section{Sample Collection and Processing}

Seven weeks after treatment application, five soil cores (5 $\mathrm{cm} / 2$ in diameter, $31 \mathrm{~cm} / 12.4$ in depth) were removed from within each quadrant. Coring locations were selected by random azimuth at a distance of $15 \mathrm{~cm}$ (6 in) from each injection site. Immediately after removal, cores were placed in refrigerated storage until all samples had been collected.

A hydropneumatic root elutriation system was used to separate fine roots (less than $2 \mathrm{~mm}$ in diameter) from soil in the cores (Hydropneumatic Root Washer; Gillison's Variety Fabrication, Inc., Benzonia, MI) Roots were immediately transferred to a $50 \%$ ethanol solution and refrigerated at $4.4^{\circ} \mathrm{C}\left(39.92^{\circ} \mathrm{F}\right)$ until further processing. Roots greater than 2 $\mathrm{mm}(0.08 \mathrm{in})$ in diameter were not considered in this experiment.

Fine roots obtained from each soil core were suspended in water in a transparent tray and scanned on an Epson Expression 1680 flatbed color scanner (Epson America, Inc., Long Beach, CA). The root length of each sample was measured using WinRhizo software (Regent Instruments, Inc., Quebec, Canada), and this information was used to calculate the root length density ( $\mathrm{cm}$ root $/ \mathrm{cm}^{3}$ soil) of each soil core. The root surface area density $\left(\mathrm{cm}^{2}\right.$ root surface area $/ \mathrm{cm}^{3}$ soil $)$, the root diameter distribution, and the mean root diameter $(\mathrm{mm})$ were also measured. After scanning, root samples were oven-dried for $48 \mathrm{hr}$ at $70^{\circ} \mathrm{C}\left(158^{\circ} \mathrm{F}\right)$ before dry weight measurement and calculation of root mass density ( $\mathrm{g}$ root dry weight $/ \mathrm{cm}^{3}$ soil).

\section{Statistical Analyses}

The effects of soil treatment on root parameters were analyzed using a $2 \times 2$ factorial analysis of variance with subsampling (SAS PRC GLM, SAS version 9.0; SAS Institute, Cary, NC). Mean separations were performed with Fisher's least significant difference. Treatment main effects and dependent multiple comparisons were evaluated at the $\alpha=$ 0.10 significance level as a result of the marked spatial heterogeneity that characterizes belowground data.

\section{RESULTS AND DISCUSSION}

Terravent treatment, with or without injection of a liquid soil amendment, did not alter the amount of fine root length present in a moderately compacted clay loam soil 7 weeks after 
Table 1. $P$ values associated with the main and interactive effects of Terravent ${ }^{\mathrm{TM}}$ injection (TV) and MycorTree ${ }^{\mathrm{TM}}$ product application (M) on four root parameters of red maple trees growing on moderately compacted soil. $^{2}$

\begin{tabular}{llll}
\hline Parameter & $\begin{array}{l}\text { TV main } \\
\text { effect }\end{array}$ & $\begin{array}{l}\text { M main } \\
\text { effect }\end{array}$ & $\begin{array}{l}\text { TV } \times \text { M } \\
\text { interaction }\end{array}$ \\
\hline Root length density $\left(\mathrm{cm} / \mathrm{cm}^{3}\right)$ & 0.1739 & 0.2875 & 0.4984 \\
Root mass density & 0.4371 & 0.0613 & 0.9788 \\
$\begin{array}{l}\text { Root diameter }(\mathrm{mm}) \\
\text { Root surface area density }\end{array}$ & 0.9595 & 0.0628 & 0.8471 \\
$\quad\left(\mathrm{~cm}^{2} / \mathrm{cm}^{3}\right)$ & 0.3333 & 0.0968 & 0.8140 \\
Root tip density (tips $\left./ \mathrm{cm}^{3}\right)$ & 0.4624 & 0.4988 & 0.0783 \\
\hline
\end{tabular}

${ }^{\mathrm{z}}$ Roots less than $2 \mathrm{~mm}$ (0.08 in) in diameter were surveyed. Analyses of variance were performed using SAS PROC GLM (SAS version 9.0; SAS Institute, Cary, NC).

treatment. Terravent treatment also had no effect on root diameter, surface area density, or mass density (Table 1). This result is consistent with results obtained with earlier soil-fracturing devices.

In previous studies, neither the Grow Gun (Grow Gun Corp., Arvada, CO) nor the Terralift (R.E. Jarvis Co., Fayville, MA) produced measurable improvements in trunk diameter growth of four landscape tree species (Smiley 1994). These devices also had inconsistent effects on soil bulk density (Smiley et al. 1990; Rolf 1992). Although they did increase oxygen diffusion rate (ODR) along soil fracture lines, ODR in the bulk soil outside of the fracture lines was unaffected (Smiley et al. 1990). The Terravent has also been shown to have no effect on soil bulk density, and Smiley (2001) has suggested that the volume of soil actually impacted by the fracture planes may be too small to significantly affect soil physical properties or tree growth. Positive growth responses attributed to injection devices may result primarily from materials that are released into the fracture planes after the initial injection (E.T. Smiley, pers. comm.).

In our study, root length density was also unaffected by the addition of a liquid soil amendment. However, treatment with the liquid amendment, both alone and in conjunction with Terravent injections, was associated with significantly reduced fine root diameter (Table 1; Figure 1). Averaged across both levels of Terravent treatment, roots from M-treated soil had a mean diameter of $0.66 \pm 0.01 \mathrm{~mm}$, whereas those from untreated soil had a mean diameter of $0.69 \pm 0.01 \mathrm{~mm}$. The reduction in root diameter resulted primarily from the presence of greater root length in the finest diameter category, less than $0.1 \mathrm{~mm}$ (0.004 in) (Figure 2). This size class of roots is generally considered to be the most metabolically active (Wells and Eissenstat 2001).

Smaller mean root diameter, combined with unchanged root length, resulted in reduced values of other root system

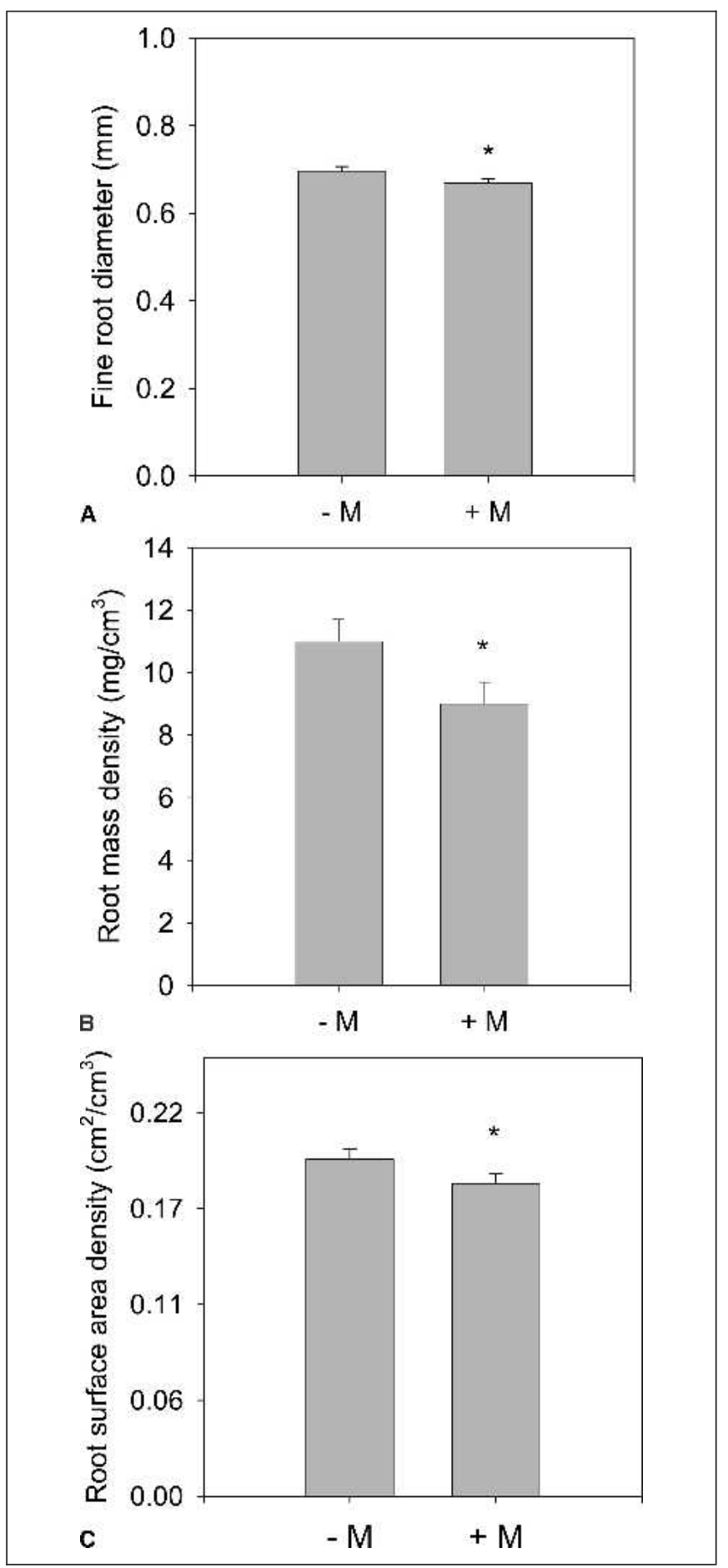

Figure 1. Mean (A) fine root diameter, $(B)$, root mass density, and (C) root surface area density in soil cores removed from areas treated with and without a liquid soil amendment. Roots less than $2 \mathrm{~mm}(0.08 \mathrm{in})$ in diameter were surveyed. Bars represent one standard error. $n=20$ for each treatment group. ${ }^{*} P<0.1 ;{ }^{*} P<0.5$. 


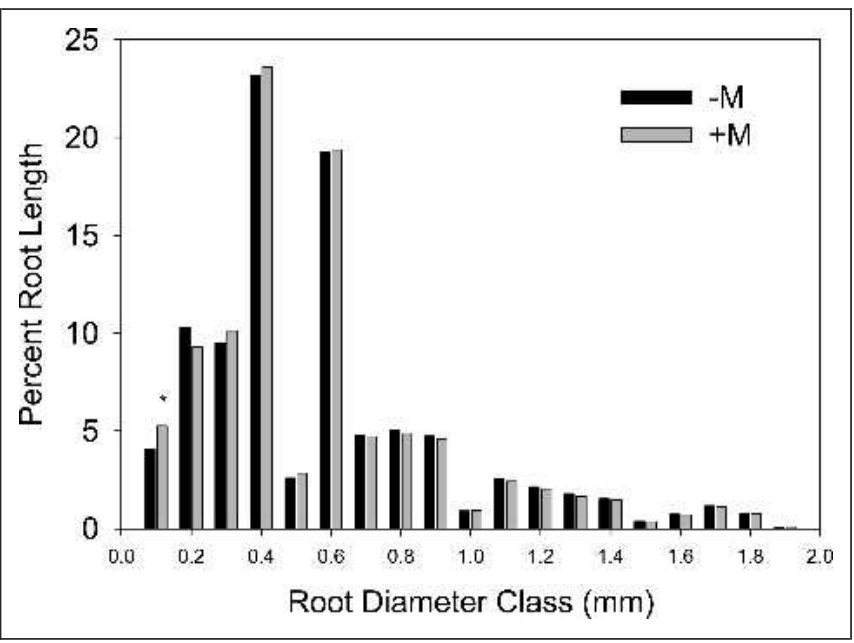

Figure 2. Percent of fine root length in each of 19 diameter classes, from less than $0.1 \mathrm{~mm}$ to 1.9 to $2 \mathrm{~mm}(0.076$ to $0.08 \mathrm{in}$ ). Fine roots (less than $2 \mathrm{~mm}$ (0.08 in) in diameter) were obtained from soil cores removed from areas treated with and without a liquid soil amendment. $n=20$ for each treatment group. ${ }^{*} P<0.05$.

parameters. Root surface area, which is a function of length and diameter, was reduced in product-treated soil (Table 1). The absolute value of this difference was quite small: 0.01 $\mathrm{cm}^{2}\left(0.002 \mathrm{in}^{2}\right)$ per cubic centimeter of soil. Root mass, which decreases per unit length as root diameter decreases (assuming no change in tissue density), was also reduced (Table 1). Again, the magnitude of the reduction was small: approximately $2 \mathrm{mg}$ per cubic centimeter of soil. Whether changes of this magnitude would be biologically relevant to a tree whose entire root system were treated the liquid amendment is unknown.

Reductions in root surface area and mass may have altered the tree's capacity for water and nutrient uptake in treated soil. However, nutrient uptake is a function of numerous parameters: nutrient availability and mobility in the soil, the extent of mycorrhizal colonization, the surface area of roots and mycorrhizal hyphae, and the affinity and velocity of membrane transporters. Factors governing rates of water influx are equally complex. Without information on changes in soil resource availability and root physiology associated with product application, it is difficult to assign functional significance to reductions in root mass and surface area.

MycorTree Injectable contains a wide variety of biotic and abiotic ingredients, and the specific ingredient(s) responsible for reduced fine root diameter cannot be identified with certainty. It is interesting to note that the number of endomycorrhizal spores present in the prepared amendment was relatively low: 64 spores per $4 \mathrm{fl} \mathrm{oz}(0.12 \mathrm{~mL})$ injection or 320 spores per $6 \mathrm{~m}^{2}\left(64.8 \mathrm{ft}^{2}\right)$ quadrant. Other authors have sug- gested that inoculum levels as high as 30,000 spores $/ \mathrm{m}^{2}$ should be applied to the root zone to encourage mycorrhizal colonization during early root development in agricultural settings (Menge and Timmer 1982; Nelson 1987). It seems unlikely that changes in root diameter observed in the present experiment were related to added mycorrhizal spores.

In conclusion, there was no evidence to suggest that Terravent treatment stimulated fine root growth in a compacted soil. This result is consistent with previous reports citing little benefit from air injection devices. Treatment with a liquid soil amendment altered root diameter distribution and associated parameters, but the mechanisms and physiological consequences of these changes remain to be characterized.

\section{LITERATURE CITED}

Day, S.D., and N.L. Bassuk. 1994. A review of the effects of soil compaction and amelioration treatments on landscape trees. Journal of Arboriculture 20:9-17.

Menge, J.A., and L.W. Timmer. 1982. Procedures for inoculation of plants with vesicular-arbuscular mycorrhizae in the laboratory, greenhouse and field. In N.C. Schenk (Ed.). Methods and Principles of Mycorrhizal Research. American Phytopathological Society, St. Paul, MN.

Nelson, S. 1987. Rooting and subsequent growth of woody ornamental softwood cuttings treated with endomycorrhizal inoculum. Journal of the American Society for Horticultural Science 112:263-266.

Patterson, J.C., and D.L. Mader. 1982. Soil compaction: Causes and control. In P.J. Craul (Ed.). Urban Forest Soils: A Reference Workbook. SUNY College of Environmental Science and Forestry, Syracuse, NY.

Rolf, K. 1992. Soil physical effects of pneumatic subsoil loosening using a Terralift soil aerator. Journal of Arboriculture 18:235-240.

1994. Soil compaction and loosening effects on soil physics and tree growth. In G.W. Watson and D. Neely (Eds.). The Landscape Below Ground. International Society of Arboriculture, Savoy, IL.

Smiley, E.T. 1994. The effects of soil aeration equipment on tree growth. In G.W. Watson and D. Neely (Eds.). The Landscape Below Ground. International Society of Arboriculture, Savoy, IL.

2001. Terravent: Soil fracture patterns and impact on bulk density. Journal of Arboriculture 27:326-330.

Smiley, E.T., G.W. Watson, B.R. Fraedrich, and D.C. Booth. 1990. Evaluation of soil aeration equipment. Journal of Arboriculture 16:118-123.

USDA-NRCS. 1999. National Soil Survey Characterization Data. Soil Survey Laboratory. National Soil Survey Center, Lincoln, NE. 
Wells, C.E., and D.M. Eissenstat. 2001. Marked differences in survivorship among apple roots of different diameters. Ecology 82:882-892.

\section{William Hascher}

Arborist Department Manager

The Biltmore Company

One North Pack Square

Asheville, NC 28801, U.S.

\author{
Christina E. Wells (corresponding author) \\ Associate Professor of Horticulture \\ Clemson University \\ Clemson, SC 29634, U.S. \\ cewells@clemson.edu
}

Résumé. Le Terravent ${ }^{\mathrm{TM}}$ (Pinnacle Concepts Ltd., Cornwall, Royaume-Uni), un outil pour l'injection dans le sol, emploi de l'azote gazeux comprimé pour fracturer le sol compacté et ainsi permettre l'injection subséquente d'amendements liquides. Dans cette étude, nous avons mesuré la croissance en fines radicelles ainsi que l'architecture des sols qui ont reçu l'un de ces quatre traitements: (1) injections avec le Terravent ${ }^{\mathrm{TM}}$, (2) injections avec le Terravent ${ }^{\mathrm{TM}}$ suivi d'un amendement liquide (MycorTree ${ }^{\circledR}$ Injectable, PHC Inc.), (3) ajout d'un amendement seul, et (4) groupe témoin sans traitement. L'expérience a été menée sur 10 érables rouges (Acer rubrum) poussant dans un sol urbain argileux modérément compacté à proximité d'une voie routière passante sur le campus de l'Université Clemson. Les traitements ont été appliqués en avril 2002. Sept semaines plus tard, des échantillons de sol ont été extraits de zones adjacentes aux sites d'injection et les fines radicelles $(<2 \mathrm{~mm}$ de diamètre) de chacun des échantillons ont été lavées de leur sol. Une variété de paramètres de ces racines ont été mesurés, à savoir leur longueur, la surface occupée, leur distribution en diamètres et leur masse. Le traitement avec le Terravent ${ }^{\mathrm{TM}}$ n'a eu aucun effet sur chacun des paramètres de racines mesurés. L'application de MycorTree ${ }^{\circledR}$ a été associée avec de faibles mais statistiquement significatives réductions en diamètre des racines, de la masse racinaire ( $\mathrm{mg}$ de racines $/ \mathrm{cm}^{3}$ de sol) et de la densité des racines en surface $\left(\mathrm{cm}^{2}\right.$ de racines $/ \mathrm{cm}^{3}$ de sol).
Zusammenfassung. Der Terravent-Bodenbelüfter verwendet komprimiertes Stickstoffgas, um verdichteten Boden aufzulockern und gestattet die subsequente Injektion von flüssigen Bodenverbesserern. In der gegenwärtigen Studie haben wir das Feinwurzelwachstum und den Bodenaufbau in Böden gemessen, die eine von vier folgenden Behandlungen erhalten haben: (1) Terravent ${ }^{\mathrm{TM}}$ Injektionen, (2) Terravent ${ }^{\mathrm{TM}}$ Injektionen, plus Bodenverbesserer (MycorTree ${ }^{\circledR}$ Injectable, PHC, Inc.), (3) nur Bodenverbesserer und (4) eine unbehandelte Kontrolle. Das Experiment wurde an zehn Rotahornen, die in einem mäßig verdichteten urbanen Tonboden in Nachbarschaft zu einer häufig befahrenen Straße auf dem ClemsonUniversitätscampus. Die Behandlungen wurden im April 2002 durchgeführt. Sieben Wochen später wurden Bodenproben aus den benachbarten Böden und die Feinwurzeln wurden freigespült. Es wurde eine Reihe von Wurzelparametern gemessen: Länge, Oberfläche, Durchmesserverteilung und Masse. Die TerraventBehandlungen hatten keinen Effekt auf irgendwelchen gemessenen Wurzelparameter. Die Applikation von Mycor Tree wurde in Verbindung gebracht mit kleinen statistisch relevanten verkleinerten Wurzeldurchmessern, Wurzelmassendichte (mg Wurzel $/ \mathrm{cm}^{3}$ Boden) und Wurzeloberflächendichte $\left(\mathrm{cm}^{2}\right.$ Wurzel $/ \mathrm{cm}^{3}$ Boden).

Resumen. El aparato de inyección al suelo Terravent ${ }^{\mathrm{TM}}$ (Pinnacle Concepts, Ltd., Cornwall, UK) usa gas de nitrógeno comprimido para fracturar el suelo compactado y permite la inyección subsiguiente de mejoradores líquidos. En el estudio actual, se midió la arquitectura y el crecimiento de las raíces finas en el suelo, que había recibido uno de cuatro tratamientos: (1) inyecciones de Terravent ${ }^{\mathrm{TM}}$, (2) inyecciones de Terravent ${ }^{\mathrm{TM}}$ seguidas de mejoradores líquidos (MycorTree ${ }^{\circledR}$ Injectable, PHC, Inc.), (3) adición de mejoradores solamente, y (4) control no tratado. El experimento se llevó a cabo con diez maples rojos (Acer rubrum) creciendo en suelo urbano arcilloso moderadamente compactado, cerca de un camino transitado en el campus de la Universidad de Clemson. Los tratamientos fueron aplicados en Abril de 2002. Siete semanas después se extrajeron muestras de suelo de las localidades adyacentes a los sitios de inyección, y se lavaron las raíces finas ( $<2 \mathrm{~mm}$ de diámetro) de cada muestra. Se midieron una variedad de parámetros de las raíces, incluyendo longitud, área superficial, masa y distribución diamétrica. El tratamiento (1) con Terravent ${ }^{\mathrm{TM}}$ no tuvo efecto en ninguno de los parámetros medidos. La aplicación de MycorTree ${ }^{\circledR}$ estuvo asociada con reducciones pequeñas, estadísticamente significantes, en el diámetro de la raíz, densidad de raíces $\left(\mathrm{mg}\right.$ raíz $/ \mathrm{cm}^{3}$ de suelo) y densidad de área superficial de las raíces $\left(\mathrm{cm}^{2}\right.$ raíz $/ \mathrm{cm}^{3}$ de suelo). 